\title{
Realising the inclusive potential of online teaching and learning for marginalised students
}

\author{
Donna Hurford ${ }^{1}$, Andrew Read ${ }^{2}$ \\ University of Southern Denmark¹, London South Bank University, UK²
}

What's the problem?

In spring 2020, in response to COVID-19, United Kingdom (UK) universities shifted much of their provision online (Baker, 2020). However, because of a number of practical and commercial factors, many universities have retained elements of on-campus provision. As a consequence, hybrid approaches to teaching and learning, combining online and on-campus components, are now widely employed by UK universities.

The hybrid model presents universities with logistical and ethical challenges. Universities offering courses which involve practice-based assessment - in, for example, laboratory environments or the creative arts and performance - face complex decisions about how to facilitate socially distanced on-campus provision. It may be impossible to replicate online the full range of resources available to all students on-campus. On top of this, pressure to make a competitive offer to new students has pushed universities to return to 'in-person' teaching for the start of the new academic year (Universities UK, 2020) and consequently to put in place safeguards to minimise the potential health risk to students.

But the provision of socially distanced, in-person, on-campus teaching presents significant ethical and logistical challenges. Black, Asian and minority ethnic students are at increased risk of infection and death from COVID-19 (Aldridge et al., 2020). The orchestration of oncampus, discrete, socially distanced groups - to enable students to have meaningful discussions, collate their thoughts and then share these in meaningful ways with other groups - could place unreasonable or unrealistic demands on students, academics and ancillary staff.

Though on-campus provision may be essential in some contexts, online approaches can nevertheless offer a more practicable alternative to the 'in-person' socially distanced teaching across the board which many universities have committed to. Online delivery may well be able to replicate - or, at least, closely match - the pre-COVID on-campus provision and thus provide a more equitably accessible offer. For example, online platforms such as Teams or Zoom allow students to move between live, face-to-face, small group discussion and live whole-cohort debate in ways that would be almost impossible on a socially distanced campus. However, course designers do need to consider how to ensure that online collaboration is both motivating and inclusive.

\section{Principles for inclusive online learning}

1. Be aware that belonging is significant.

Recognise that some students do not feel they belong to their university communities and that this can, in turn, affect their persistence, learning outcomes and final grades (Amos and 
Doku, 2019; Tinto, 2017; Masika and Jones, 2016). We must keep sight of this in our online teaching and learning.

2. Ensure that synchronous online teaching and learning are purposeful.

Acknowledge that constraints, including access to quiet study spaces and disparity in the quality of online and digital access, especially affect excluded groups - hence the need to be clear about the learning objectives and relevance of synchronous online teaching and collaborative learning activities.

3. Provide accessible guidance.

Avoid making assumptions about students' digital expertise and understanding. Provide clear, technical guidance on the online platforms; include the students in co-developing guidance on online etiquette.

4. Design inclusive online learning activities.

When designing synchronous and asynchronous online learning activities, apply a consistent design structure with which students can become familiar. In addition, design collaborative learning activities which require social interdependence and individual accountability, sending clear signals that collaboration is valued (Johnson et al., 2014).

\section{Putting principles into practice}

1. Be explicit about roles and responsibilities in the online course. Share research on effective collaborative learning (Johnson, op.cit.) and signal how the students' collaborative learning is valued in the course and its assessment.

2. Prioritise synchronous collaborative learning activities by flipping the content. Make the content available asynchronously through videos, screencasts, readings etc., with associated reflective tasks which prepare students for synchronous collaborative learning activities.

Team-based learning provides a collaborative learning framework for face-to-face and online contexts. The online class starts with a meaningful quiz based on the flipped content. The students answer individually before being assigned to teams where they share their learning, re-take the test and in most cases improve their scores (Parmelee et al., 2010). Following the team quiz, the teacher focuses the teaching on the weakest areas of student understanding and sets the teams learning activities which require the application of their new knowledge and understanding.

3. Integrate collaborative learning activities into synchronous teaching and allocate student groups to breakout rooms when using video conferencing platforms. Upload relevant resources and descriptions of learning activities to accessible online platforms, such as Microsoft Sway or Padlet, and share the link via the online platform's chat function. This way students can easily access relevant resources and learning activity descriptions. 
Online resources - like Padlet or the whiteboards provided by some online platforms facilitate resource sharing by the teacher and group-members. Each group can use its own whiteboard to mind-map or concept-map their ideas, as well as sharing uploaded resources (Novak and Gowin, 1984). In the plenary, group members can then share their individual screens with the group's whiteboard or other online resource where they have uploaded tasks or drafted their ideas.

Online teaching and learning can certainly contribute to inclusive and accessible teaching and learning. By prioritising inclusion, accessibility and careful planning, we may harness the potential of online platforms and resources for the benefit of all - and our most marginalised students will be the chief beneficiaries.

\section{Reference list}

Aldridge, R., Lewer, D., Katikireddi, S.V., Mathur, R., Pathak, N., Burns, R., Fragaszy, E.B., Johnson, A.M., Devakumar, D., Abubakar, I. and Hayward, A. (2020) 'Black, Asian and Minority Ethnic groups in England are at increased risk of death from COVID-19: indirect standardisation of NHS mortality data.' Wellcome Open Research. Available at: https://wellcomeopenresearch.org/articles/5-88/v2 (Accessed: 03 September 2020).

Amos, V. and Doku, A. (2019) 'Black, Asian and Minority Ethnic Student Attainment at UK Universities: \#Closing the Gap.' Available at: https://www.universitiesuk.ac.uk/policy-andanalysis/reports/Pages/bame-student-attainment-uk-universities-closing-the-gap.aspx (Accessed: 03 September 2020).

Baker, S. (2020) 'Coronavirus: growing number of UK universities move to online teaching.' Times Higher Education Supplement, 13 March. Available at: https://www.timeshighereducation.com/news/coronavirus-growing-number-uk-universitiesmove-online-teaching (Accessed: 03 September 2020).

Department for Education (2020) 'Higher education: reopening buildings and campuses.' Available at: https://www.gov.uk/government/publications/higher-education-reopeningbuildings-and-campuses/higher-education-reopening-buildings-and-campuses (Accessed: 03 September 2020).

Johnson, D.W., Johnson, R.T. and Smith, K.A. (2014) 'Cooperative learning: Improving university instruction by basing practice on validated theory.' Journal on Excellence in College Teaching, 25(3\&4), 85-118. Available at: ISSN: 1052-4800 (Accessed: 19 December 2020).

Masika, R. and Jones, J. (2016) 'Building student belonging and engagement: insights into higher education students' experiences of participating and learning together.' Teaching in Higher Education, 21(2), 138-150. Available at: DOI: 10.1080/13562517.2015.1122585 (Accessed: 17 December 2020).

Novak, J. and Gowin, B. (1984) Learning How to Learn. New York: Cambridge Press. Available at: DOI: https://doi.org/10.1017/CBO9781139173469 (Accessed: 19/12/2020). 
Parmelee, D. and Michaelsen, L.K. (2010) 'Twelve tips for doing effective Team-Based Learning (TBL).' Medical Teacher, 32, 118-122. Available at:

DOI: 10.3109/01421590903548562 (Accessed: 17 December 2020).

Quality Assurance Agency for Higher Education (2020) 'COVID-19: Thematic Guidance practice and lab-based assessment.' Available at:

https://www.qaa.ac.uk/docs/qaa/quidance/covid-19-thematic-quidance-practice-lab-basedassessment.pdf (Accessed: 30 November 2020).

Tinto, V. (2017) 'Reflections on Student Persistence.' Student Success: A journal exploring the experiences of students in tertiary education, 8(2), 1-8. Available at:

https://doi.org/10.5204/ssj.v8i2.376 (Accessed: 17 December 2020).

Universities UK (2020) 'Most universities will teach in-person this autumn.' Available at:

https://www.universitiesuk.ac.uk/news/Pages/Most-universities-will-teach-in-person-this-

autumn.aspx (Accessed: 03 September 2020). 